Simashenkov P.D. The research component in the professional education of history majors // Scientific and methodological electronic journal "Concept". - 2020. - № 3. - P.28 -39

\author{
Pavel D. Simashenkov, \\ $\mathrm{PhD}$, Associate Professor at Public Administration Chair, \\ IMI University, Samara, Russia \\ pavel.simashenckov@yandex.ru
}

\title{
THE RESEARCH COMPONENT IN THE PROFESSIONAL EDUCATION OF HISTORY MAJORS
}

\begin{abstract}
The article is devoted to the topic of "traces of the past" interpretation; its relevance is due to both the need to improve the training of history majors and the aggravation of the fight against falsifications of history (primarily domestic). The aim of the research is to analyze the correlation of humanitarian, social and technological components in the methodology of teaching historical disciplines. The comparative method was chosen as a key method. The work uses the method of hypotheses, content analysis of the source base, and experience in studying University teaching practice. Identifying the prerequisites for "incorrect" interpretation of historical events, the author compares legal, forensic and philosophical approaches.

The theoretical significance of the article lies in the novelty of an interdisciplinary, integrated technosocial humanitarian outlook on historical research. According to the author, the best way to overcome bias is adherence to principles; a person must inspire and justify trust: this requirement is true for both a forensic expert and a scientist. The main thing is to avoid simplifications, geometric sketching of the past, reducing it to parallels and piles of additional constructions, politicized speculations. No less great is the temptation to fall into exegesis, and from the interpreter of texts to become the owner of stylization and meta-history. The task of the researcher is to reveal the specifics of the typical. It is extremely difficult to find the "median nerve" of an era, but this is the only way to "qualify the subjective side of an act" from a historiosophical perspective. The sensation and awareness of belonging to humanity obliges the scientist to think in integral, complex, figurative, and not abstract categories. Intersubjectivity itself (even intrasubjectivity) characterizes history as a humanitarian science, and not as narrowly social one (akin to jurisprudence or sociology, especially in their positivistic interpretations). The practical significance of the study lies in the fact that the material of the article can be used in the pedagogical process, and a comparison of fundamental and applied disciplines will help history majors to sort out professional and worldview issues, and teach them to distinguish between the eternal and the vain-trendy, the ideological and the tendentious. History, the author believes, is about the eternally alive, and not about the outdated things.
\end{abstract}

Key words: history, philosophy, criminalistics, trace evidence, comparative studies.

\section{Introduction}

The work of Andreas Buller "Three Lectures on the Concept of "Trace" [1] was the source of inspiration during writing the article. Referring to Western historiosophical concepts, Dr. Buller substantiates the non-trivial vision of the trace problem in history, conceived in abstract and speculative way. Having many years of forensic expert experience, we take a risk of interpreting the question literally, and therefore in the same way legally precisely and associatively, developing the conceptual apparatus of the lectures mentioned - intending to find out what (history or forensics) is 
playing on a foreign field. We will try to go beyond comparing the historian with the constable made by the wise R. Collingwood [2].

Historical distance is not just inevitable, it is necessary and somewhat useful for understanding and evaluating the past. On the contrary, in detective practice, cooling off a "hot trace" complicates the investigation. Continuing the analogy, it is worth mentioning the difference between a detective story and a police action movie: in the latter, the offender is already known, and all the charm is not in intelligence, but in pursuit, in action. It is even "simpler" in case of history: here, as a rule, not only the identities of key characters are established, but the plot's final itself is known. How great is the temptation to falsify the traces, chasing the sensation and tailoring the puzzle to a predetermined answer! Comparing historical studies to detective stories, with some similarities in details (however, purely external), looks in general rather awkward, and therefore we prefer the inductive method to Holmes' deduction, which allows us to synthesize, in our opinion, more capacious generalizations.

Twenty years of teaching experience at the university give moral right and good reason to assert: interdisciplinary relations in the academic courses of the humanities are not fully and clearly presented (perhaps, due to the narrow specialization of teachers). In particular, studying philosophy, legal and natural science subjects by future historians has little to do with their professional competences. We believe that comparison of fundamental and applied disciplines will help history majors to judge fairly about professional and (most importantly) worldview issues, learn to distinguish between the eternal and the vain-trendy, the ideological - from the tendentious. Accordingly, the logical structure of this article is due to the interpretation of the "traces in history" problem in a comparative, interdisciplinary manner.

\section{Review of Russian and foreign literature}

Declaring the "historical-traceological" approach to be scholarly new, we recognize, however, that the issue of traces was fragmentarily covered as an aspect of historical knowledge theory. Foreign researchers are predominantly concerned with reflection issues. J. Rüsen [3] distinguished historical self-reflection and intercultural historiography; O. Oexle [4] called history a scientifically justified memory of the present; W. Wrzosek [5] said that the relation of modern historical science to the past - especially distant past - is none other than the relation of the culture to another culture. No less interesting is the search for a coordinate system that outlines the regime of historicism. For example, R. Koselleck [6] believes that historical interpretations are caused by the cognitive situation in which the historian lives; F. Hartog [7] develops the subject of the transformation of memory into history; W. Benjamin [8] writes about the shaky present and constancy of the so-called Angel of history. Western intellectuals are trying to streamline the past scholastically, administratively, from above - as if they invented and patented absolute truth. The result is tricky and neat mental constructions, which essentially are the kinds of Goldberg variations based on a thousand year-old dispute (between realists and nominalists). Actually, any paradigmatic ordnance, volens-nolens, fabricates the universal "enlightenment technology", and the inevitable disappointment in it will give rise to another attack of negative dialectics. Perhaps for this reason bourgeois philosophy is saturated with nostalgic pessimism, a kind of anemia of faith: both in the human cognitive abilities and in the highest purpose of everything that happens, whereas, according to G. Chulkov, "history requires human courage, but you cannot be courageous if your moral consciousness constantly reminds to you about the sinfulness of the whole historical process "[9]. Modern European authors (for example, M. Cattaruzza [10]) very delicately and cautiously introduce the worldview component 
into the system of historical knowledge. Perhaps, A. Buller's beautiful aphorism can be recognized as the most "radical" in this regard: "History is the morality realized in time" [1 1 ].

Many "conceptual twists and turns" (cognitive, anthropological, psychological, memorial, and many others) turned the Western historiosophical vector 360 degrees, motivating scholars not to lose their way between the three trees of the past, future and present (passeism, futurism, presentism). As a result, there are expected reminiscences: Dr. Buller calls for arming with the skepticism of Droysen and Collingwood [12, 13], and W. Wrzosek admires the critical potential of the theories of Chladenius and Vico [14]. It is time to recall Saltykov-Shchedrin: "Left to its own devices and turning in a too homogeneous environment, a thought can achieve painful, almost monstrous results" [15].

Domestic philosophy more organically (by no means in the vulgar, social-evolutionist edition of Darwinism) comprehended the idea of development, where phenomena are grouped according to observations, established laws and identified directions. Hence the natural ordering, greater integrity, "artistry" and fewer -isms in attempts to grasp the immensity (it suffices to compare the cultural and historical types of N. Danilevsky [16] and the cultural ranks of H. Rückert [17]). N.Nadezhdin defined history as "full, bright, vibrant self-awareness of every nation" [18]. In Russia, historiosophical moments were interpreted mainly from an ideological perspective. M. Pogodin [19] defended the theory of official nationality, N. Strakhov [20] shared the ideas of Pochvennichestvo (roughly - return to the native soil); P. Lavrov [21] connected historical development with the activity of critically thinking individuals. And later, the indicated moral and aesthetic direction as a whole was preserved. For example, L. Gumilev [22] developed the doctrine of passionaries (super activists), and B. Mogilnitsky [23] wrote about the specificity of historical laws and the alternative character of cognition.

Ethical leitmotif can be traced in the domestic pedagogical literature as well. Already in the first Russian manual on the methodology of teaching history, Y. Gurevich, its author, persuaded "to exert influence on the moral and mental development of students by means of material impartation and the way of presenting it ... For this, there is no need to hide gloomy events in the history of the nation and put forward only bright events in our life. For this, there is no need to idealize the past of our people and humiliate the significance of other peoples: such blind patriotism is completely opposed to a sense of truth and humanity, the development of which the school should have in mind" [24]. A modern view of the problem of "digitalization of teaching history" is in line with the same civil-patriotic dominant [25].

Thus, domestic and foreign historiosophical schools, legally speaking, are examples of caselaw and normative approaches to assessing evidence. The first comes from traditions and analogies, the second from formally established prescriptions; one focuses on the system and principles, the other on structure and dogma. In a word, Western philosophy is strong with rules, and Russian philosophy is alive with exceptions.

\section{Methodological basis}

Refined phrasally, foreign "historica" (as the discipline philosophy is called there) is pressed down by the "cultural layer" of terms (constituent myth, cultural code, axiological neutrality, sociocultural factor, etc.), the explanation of which is worth establishing an independent quasiscientific discipline. Therefore, we are not surprised by the abundance of talk and often fantastic reasons for discussion, or by the emergence of "police" language, such as historical postscripts, falsifications, feints, false conclusions, qualifications of the phenomena meaning; that is why 
historiography gradually mutates into graphology (which is recognized as pseudoscience by the way). It seems that all the efforts of the ancestors were devoted solely to concealment of traces and evasion of responsibility. But what is historical responsibility and (most important) - when and to whom to answer? This formulation of the problem seems to be fundamental for us, since it will allow us to distinguish the providentialists from the determinists, and art from artificiality and hackwork. In our opinion, the Western course towards the "legitimation" of historical comprehension is largely erroneous. Casuistry distills history, and the absolutization of "objectivity" is nothing more than a manifestation of pride (which intends to privatize the truth), that is, ultimate subjectivity.

The legal coordinates of the "objective-subjective" easily reveal the "tribal curses" of historians: formalism and tendentiousness (correlated, most likely, as a cause and an effect). With regard to the topic of traces and investigations, formalism is generally a structure forming criterion. Is the historian's mission limited to the commission of an expert collecting and analyzing evidence? In this situation, the function (not even the mission) of an expert is to give an unambiguous (nonprobabilistic) answer to the questions posed on the basis of the generated investigative version. Moreover, the version is nothing more than a polarized (biased, as an option) picture of events, as long as the process is divided into prosecution and defense parties. This means that the issue of accuracy and specificity of conclusions becomes central. It is the unreserved character of the expert assessment that is especially highly valued here, for law is a dark woods of reservations by definition, where every lawyer is Susanin and there is no one Danko.

It is worth noting that legal rhetoric has been present in the "procedure" vocabulary of scientific citations for more than half a century "according to Leontyev's statement, Berdyaev recognized, Belinsky later repented, Karamzin confessed, Nestor directly names, Herzen testifies," etc.). Historical characters are defenseless against (re)searchers-investigators practicing interrogations under torture, manipulating information that is not always arguments and facts. Unlike testimonies, even memoirs are not interactive; they are peculiar answers without questions, a signed blank sheet of the case statement, which can be added with the hand of an unscrupulous detective. It turns out that in case of failure to appear (due to death) of the person involved, his own preserved confession is formally Regina probationum. Thanks to this "objective imputation", unpretentious hypotheses also appear - like the one that Afanasy Nikitin converted to Islam (according to allegedly "Muslim" passages in his "Walking over the Three Seas") or that the above mentioned "queen of evidence" is an aphorism of prosecutor A. Vyshinsky.

Therefore, the root of formalism lies in the non-selectivity of the method, since the research methodology must be approved by the competent authority. Otherwise, the results of the examination cannot be recognized as evidence. Moreover, a forensic expert is responsible for a knowingly false conclusion, but is the scientist responsible, and again, "who are the judges?" Certainly, the court of history that has been hoped for centuries will also hear a historian: as an expert or a witness. The latter is worse, because it presumes mistrust: why he intends to interpret events? We believe that they do not establish and restore the truth (who lost it?), they gain it. Here the revelation is higher than formal logic, diagnosis is more accurate than identification, and doctrine is more valuable than manuals. Perhaps that is why the phrase "History will judge us" will be relevant until the Last Judgment; the departed hopes for this as if for trial by ordeal that differed from torture because it was scheduled also by the will of the defendants. In this, we think, the hope of people for higher justice is manifested, irrespective of pedantry and pettifoggery.

Let us exacerbate our discussion of legal antiquity with one more thesis: truth is always "barbaric", it is not an impassionate noble "verity". The historian is not only an investigator, but also a 
victim (like all mortals): both from history and sometimes because of history. This means that the need to find and expose the guilty person in front of society is very much in the spirit of the memorable leges barbarorum. Is it permissible to speak seriously about complete disinterest of historians in the results of their own researches? Especially in the era of politicization of everything and everyone, when they pay a high price for fomenting an unhealthy interest by any means, not disdaining noir-PR and other indecent public relations. According to J. Huizinga [26], "historical knowledge is one of the forms in which society becomes aware of itself". We would like to believe that it is not the historian who reports, and the reported ones are not homo ludens or homo politicus, but serious people. In our opinion, an individual's moral readiness to become an instrument of justice is significant, but how many of us have such dedication? In customary law (lex communis), moral values that a priori surpass formalism were venerated as the test of deed. Ultimately, what is the court for: for the sake of punishment or ad maiorem Dei gloriam inque hominum salutem? Only those who in the "barbaric truth" are imbued with participation in the common cause, ready to fight for justice and live "for that guy" will be true. This implies a higher authority - collective Person. In the words of M. Ancharov, "in order to understand himself, a person must become more complex than himself. And what could be higher than a Human? - Humankind!" [27].

Questing is more a profession than investigation and inquest. There is, however, a simplified and utilitarian version "from the evil one" - persecution (let us say, revisionism - as a means to settle accounts with the dead and thereby gain cheap authority). Events and traces are always more prominent in an oblique light: in a historical context, a simple optical mode looks almost an apology for tendentiousness. It is noteworthy: before the Enlightenment, chroniclers hardly feared this sin. Probably because, like I. Yasinsky, they considered tendentiousness to be "insincerity and a sister of mediocrity" [28], because they created their opuses, trying not to offend Eternity with vulgarity. The forensic reduction of history leads to the standardization of research methods, reducing them to algorithms. This way, it is easier to invent sensational revelations by speculating in archival compromising materials. "Elementary, my dear Watson" - this is where the current demand for conspiracy theories and "historical" detectives a la Dan Brown comes from.

Biased juggling is a form of falsification, an occasion and means to design myths and sculpt historical stereotypes. Legislation reflects the devaluation of values - therefore, it is natural to predict the reduction of historical science to trends that are always sketchy, and therefore caricatured. Moreover, if the course of time is interpreted in the spirit of the legal principle of inevitability, then historicism is a negative term, almost a forensic one. Indeed, it is easier to witness death (collapse, decay) as the absence of signs of life, while its presence is a much more subtle and less objective issue. In the second option, the expert at best tries to qualify the severity of damage (again, as the lack of health, physiological and functional integrity of the body). It is true that "the whole success of natural science lies in the fact that the attention focus is moved from causes to effects" [29].

Let us emphasize, we do not deny the importance of the technical criminological component of research in private sectors: archeology (where the kinship is, perhaps, the greatest), paleography, and onomastics. Areas that are more general should be "detectiveized" much more carefully. Every scientist is somewhere arbitrary and lynching, but it is doubtful that the inevitable "court of history" will be held in absentia and on the basis of historiography only. The feeling of belonging to Humanity obliges the historian to think in integral, complex, figurative, and not abstract categories. Intersubjectivity itself (even intrasubjectivity) characterizes history as a humanitarian science, rather than a narrowly social one, akin to jurisprudence or sociology (especially in a positivistic 
interpretation). Nor should history flirt with technological effectiveness, inconceivable without a project approach and its inherent one-sided limitation because of "moronic amazement with its epoch" (Pushkin's phrase). Tendentiousness is not a worldview category; on the contrary, it is conditioned by the extensibility of life guidelines (not principles) and grows out of the vulgar aspiration for self-realization. The best remedy for bias is adherence to principles (outside of ideology, however, it can degenerate into rigorism). A person should inspire and justify trust - this is true for the requirements of both a forensic expert and a scientist. But what to trust and how to trust a moral-amorphous subject? And "who is more valuable for mother-history": a self-affirming politician-faultfinder or a meaningfully silent "trace"? The context of historical discourse is usually set by reality when it is necessary to evaluate the past in order to realize somebody's place in the present. Ancestors would be unpleasantly surprised by the scientists' interest in their petrified feces, because they left temples to the coming generations! In the past, chronicles described the acts of kings, heroes and saints; now every social infusorian thinks of itself as a shoe from Louboutin and as a blogger. We have insta-stories instead of history, unsuitable attempts to litter eternity with standard content. Because of the media, life has been turned into a continuous muddy stream of unconscious being. In other words, there are a lot of traces and those who want to leave them, but they are all alike to the point of confusion, practically indistinguishable, because they are depersonalized.

In such an "environment of non-obviousness," the historian needs not so much identification techniques as the talents of diagnostics and attribution (which is a search for the typical in a loose aggregate of the standard). This implies the presence of an internal conviction, a kind of "instinct of truth" in assessing evidence. It turns out that at the stage of fixing traces already, criminological determinism should respectfully give way to less accurate methods and more subtle matters. Just as the eye of the artist cannot fix moving objects, the aesthetics of history is in its statics, in eternal values, and anything transitory is tendentious decor. It has long been considered advantageous to go in for charlatanism: playing up to the temporary conjuncture, effectively sacrifice temporal patterns, identifying them with coincidences, passing symptoms for syndromes. Take for instance the current assortment of pseudo scholarly kitsch: pop histories, folk histories, alternative histories etc. Yet, from a historical perspective, custom-made cover-vestments [30] and divestments [31] are equally doomed to oblivion. Or to a curse, as it happened with the hysterical types of the perestroika era. However, moral purity will inspire even distant descendants.

\section{Research results}

We see the dignity of the researcher not so much in detached objectivity as in the virtues of conscientiousness and humbleness: you should "love yourself in art" less. Conscience is higher than reflection, it is Svetlov's line: "How will I face the world, how will it look at me?" In this regard, chroniclers are a vivid example: we dare to assume that the history of Russia was written by internal emigrants - monks who were alien to politics, success and self-realization. Of course, the events in their presentation were mixed with legends, signs and rumors. Nevertheless, these rumors were (in a sense) a cut of public opinion. In a word, the chronicle tradition is more likely true than accurate: the spirit of the times in it was not cluttered with accounting of facts.

The historian's task is to reveal the specifics of the typical. It is extremely difficult to find the "median nerve" of the era, but, we believe, this is the only way to comprehend the "subjective side" of an act in a historiosophical manner. M. Prishvin defined the type as "the social crystallization of the former individuality" [32]. For example, Raskolnikov's tragedy is extraordinary and contrasts with the 
typical surroundings of "Dostoevsky's Petersburg". But the story of professor-ripper from St. Petersburg [33], on the contrary, is frighteningly typical of the era of sluggish breakthrough. It is unequivocal and one-dimensional, it is savagery in the highest degree of concentration, which has absorbed staged patriotism, and mummery of science, and role-playing games, and fifty shades of adultery volunteering. Illusory life, death-show, crime management and punishment marketing [34]. It is interesting, how Napoleon Buonaparte is guilty of both murders; what will historians, reenactors and forensic scientists say?

Everyone wants to deserve hagiologic writing, or at least an obituary, but not personal particulars only. It is impossible to feel the spirit of an epoch without knowing the attitude of the people living then towards non-being. "Memento mori" sets up the vector of the "blindness" of life, for there are traces of life, but signs of death (remember the common phrase "I ask you to blame my life for my death"). As V. Klyuchevsky said, nature gives birth to people, their life buries them, and history resurrects them, wandering around their graves. Traces are fixed in signs of dying, crisis, involution as processes (and death is a fatal result). It is necessary to distinguish between orienting and reliable signs of death; it is the same in the analysis of the declines of empires and civilizations (the former do not stand the test of greatness, the latter - of satiety). Symptoms of degradation are not related to place and time. As well as the nature of the "supravital reactions" of the deceased empire, when they try to restore it in separate manifestations, re-construct it technologically ugly the product always resembles a Golem or a Frankenstein monster. So, the dead is the traceaccepting object, while the living is the trace-forming one. It turns out that history is miraculously written on the shroud of biological anthropology, like a miracle of the Sindone di Torino!

Finally, let us decide what we consider to be the trace: either it is evidence per se, or only the source of evidence. Either it is simply a product of historical metabolism, or an attribute of eternity (and then the researcher himself is a person much more ephemeral and figurative). Marc Bloch's formula defines a trace as "a sign accessible to our senses, left by a phenomenon that in itself is inaccessible to us" [35]. Note that the inaccessibility in terms of history, as in forensics, is not so much physical as procedural, that is, ultimately ritual, ideological. Moreover, the mentioned phenomenon (as "the reality given to us in sensations" [36]) can have different nature; it is dangerous to draw direct conclusions by identifying the phenomenon with the fact, and the trace with the source. It seems to us that the trace in history is a reflection, and always perfect one (even if on a material medium), imprinted in the mind and cultural memory. In historical studies, it is especially difficult to distinguish between the trace and the substrate on which it stays. Therefore, it depends largely on perception if we consider it to be a sign or not.

What leaves a trace on whom - that is the question. According to K. Marx, "as long as people exist, the history of nature and the history of people mutually determine each other" [37]. The assessment of the past is close to the truth if it is incontrovertible either by new sources introduced into scientific circulation, or by fresh archaeological discoveries. Translated into legal language, the qualification of the deed is correct when newly discovered circumstances are not able to change it radically. Thus, exploring the left sign, we must "elevate" it from the content and context to general understanding of the situation, because time heals precisely in the sense of restoring a holistic view of the past. As always, gaining such a perception brings the risks of being vulgarized before being reduced to a single denominator (or even to a sign). Unification the view of humanity (and its history) is possible only from the point of view of stupidity, which is brilliantly proved by Erasmus Roterodamus. However, this is no reason to put stupidity and death among universal human values. 
The succinct aphorism of T. Granovsky "The process of history lies in the decomposition of the masses with thought" can be interpreted both in progressive and regressive way. In our opinion, the ability to catch and recognize the spirit of the time in concrete signs requires not only awareness of the facts. Identification requires more art than investigative-experimental reconstructions do. Here, a huge role is played by special signs, consonances and dissonances, "strong and weak shares", that is, the events that were shocking and those that no longer amaze contemporaries figuratively speaking, the "pulse pressure" of history is verified according to them. Of course, this point of view is more suitable for studying natural social trends, which are only deterioration and degeneration [38]. The notorious "course of things" is a fatal imprint, a static trace, a stamp of political and economic reality basis. History of the masses is written according to this outline (the influence of events on people), and personalities are characterized by denoting the attitude of a person to fateful events and participation in them. If history is not fixated and develops, it means that a thinking person has come out from the mass; someone violated, rose above the laws of causality by creating his own context. Outstanding, creative personalities leave a dynamic trace (influence) in the soul of the people, and the deeper is the trace, the more history depends on characters. These are "identifiers" of history that individualize culture. A. Khomyakov felt keenly such moments, therefore his historiosophy is higher than formal consistency, logic and linearity (on the other hand, it cannot be called unsystematic, illogical and non-linear: Khomyakov did not think in alternatives, as they still do in the West). In the grand scheme, the essence of history is unchangeable. Since the time of ancient Greek tragedies, it has been in the relationship of a hero, a choir and gods: a person, masks, and -isms, seeking to use it.

\section{Conclusion}

Inheritors of the ancestors, we go after them, and paradoxically - into the future, towards Humankind. But what kind of heir is from the investigator in the testamentary cause? What is the historian: an expert, jury, judge, mediator or medium? Is history made mediocre by mediation with a lot of unconscious information?

The actual separates and estranges us from eternity. According to $\mathrm{H}$. Bergson, "as soon as reality creates something unpredictable or new from itself, it throws its image behind itself into its uncertain past" [39]. Objection: reality has a created nature, but does not create itself. Reality is a fact vulgarized by everyday life, a daguerreotype of the real, turning into either positive or negative according to illumination. Recognizing the providential nature of history, we are more likely to focus on the enduring - therefore, to exceed the laws, as long as they regulate only the mechanisms of involution and the trajectory of the fall. Prophecy craze is from the loss of a sense of reality. In fact, the prophecies are heard where reality is considered to be chaotic. Prophetism is rarely optimistic, because progress is a dream, not a prophecy. Moreover, divination is not a revelation; prophecies always come true retroactively (in this form they are sold to the masses). It is important not to be hardened by the news of the day, so as not to overlook the general behind the particular.

The main thing on the way of research is to avoid simplifications, geometric schematization of history, reducing it to parallels and piles of additional constructions, politicized speculations and universal techno-philosophical "slow cookers of meanings". It is no good to turn the famous Heidegger's "Dasein" into appealing verbal design, as earlier they debased psychoanalysis to the Hollywood's version of Freud explaining "supposedly everything". Mental counterfeits (awkward generalizations and false actualizations) tempt with their accessibility, so it is more dangerous to confuse historical works with indictments. No less great is the temptation to fall into exegesis, and 
from the interpreter of texts to become the owner of stylization, meta-history, and author's "exclusive" worlds (that is why the "lying sagas" (lygisögur) a la Potter's adventures or Middle-earth are so popular).

In our time of total digitalization, when existence is ahead of consciousness and the world is sliding into virtual fiction (lies and hypocrisy are already called digital intelligence), a sense of reality is supported exclusively by memory. The instinct of cultural self-preservation is manifested in a craving for the genuine, and this genuine is always in the past - this is undeniable, as a prejudicial fact. Actually, history differs from the natural processes because "phenomena in it are not repeated and happening events remain only as recollections for it" [40].

Antiquity is complicated and a refined image is restored (not reconstructed!) by the cultural memory. The past is not always the past; it lives in us. As Tyutchev said: "I have met you, and everything that had happened came to life again in my old heart... and now sounds, that never became silent in me, are heard louder." Bygone days are the past that has not passed. And the lost moments are gaps that need to be filled without destroying harmony (therefore, some of them are tactfully filled with silence). "The new is the well-forgotten old" - it is by no means a cliché; however, it is sometimes difficult to distinguish the "spirit of history" from the stuffy retro-amber in the novelty. Thus, the artificial attempts of ceremonial myth-making, tagging and branding of history by "innermost people" [41] and \#wecandoitagain make the present fast-held majestic panegyrics antihistorical and anti-popular. Certainly, we are far from declaring forensic science (much less history) to be the "party affiliation"; however, the old principle "cujus regio, ejus religio" cannot be discounted, comprehending something too human. A. Gurevich recognized the presumption of "otherness" as a postulate of historical cognition [42]. In our opinion, the problem is not in "otherness", but in recognition of the relationship with the culture. Moreover, the historian always explores culture, whether dealing with personalities, artifacts or events. Not feeling this spiritual, almost mystical contemporaneity (as in T. Powers' novel "The Anubis Gates") - it is a sin to attempt to decipher the symbolism of the "traces". Native reality is always closer, you take on a greater responsibility both to yourself and to your ancestors. A critical trend in historiography will take precedence until imitation (nigredo) has outlived itself. Consequently, the folk character of history is a necessary stage (albedo) of the synthesis of collective memory and national culture into a common memory (rubedo). Note: the most insightful of foreign scholars $[43,44]$ are on the path to understanding the importance of cultural memory (as a tuning fork for historicism) and the role of the collective Person in its formation. History is the heritage of Humankind, the unity with which we all once have to realize.

The issues of memory and history proportionality remind disputes about the difference between transubstantiation and trans-elementation. These are definitions again: if we consider memory as a physiological function of the brain, then history is immeasurably higher than any memory. On the contrary, recognizing the latter as a universal repository of knowledge and experience, history should be considered as one of the pantries from where information can be extracted depending on the means of detection and fixation. As you can see, the second approach risks becoming frankly technological and presumptuous self-sufficient, like everything technological. The obstacle is in the selectivity of memory (especially historical one); its secret has not yet been revealed, it is this selectivity that allows us to rely on the "court of history". Probably the truth will be revealed not even by the court of history, but trial of it, which will happen on Judgment Day.

According to the paradox of V. Tendryakov, "history is the most dynamic process in nature. Historical science, alas, is perhaps the most static of all sciences" [45]. Our interpretation: static - 
because one way or another it is focused on the acts of supra-historical personalities. In the words of P. Lavrov, these are "martyrs whose legend would far outgrow their true dignity. They will put into their mouths the best thoughts, which their followers have invented. They will become an unattainable ideal for the crowd". In the masses, humanity can be found in trace amounts, and socalled society is nothing more than a trace of conciliar Humankind on Earth. Poets, sages, saints, revolutionaries of all times and peoples are spiritually related and consistent, they inspire hope for the existence of Humanity, which is personified progress. In other words, they form a constant, direct component of the historical current, while impersonal but visible (scientific and technical) progress forms its variable (alternating) and is found in the masses. It turns out that the latter are both a trace-forming and a trace-perceiving object, while their purely investigative study limits history to a social (objective) component, at the expense of humanitarian one.

We are sure: the general outcome (not the goal) is in the historiosophical implementation of all historical disciplines, just as the legal branches will reach at last the primary source (legal theory). Aeon lives in cultural memory, but, alas, history is increasingly content with chronos. You should not reduce the poetry of anthropology to prose and phrase. History, in our opinion, is about the eternally alive, and not about the outdated.

\section{References}

1. Buller A. Three lectures on the concept of "trace". - M.: Aletheia, 2016 .- 128 p.

2. Collingwood R. G. The Idea of History. - Oxford University Press, 1994 -- 576 p.

3. Rüsen J. Some Theoretical Approaches to Intercultural Comparative Historiography // History and Theory. - 1996. - Vol. 35. Theme Issue: Chinese Historiography in Comparative Perspective / Ed. by Axel Schneider and Susanne Weigelin-Schwiedrzik. - P. 5 - 22.

4. Oexle O.G. Culture, the science of culture, the historical science of culture: reflections on a turn towards the sciences of culture // Odyssey. The man in history. - M .: Nauka, 2003 .- P. $393-416$.

5. Wrzosek W. In Search of Historical Time. An Essay on Time, Culture and History // Narration and Explanation. Contributions to the Methodology of the Historical Research (seria Poznań Studies in the Philosophy of Sciences and Humanities 41) / Ed. by J. Topolski. - Atlanta-Amsterdam, 1990. - P. 119 - 131.

6. Koselleck R. Futures Past. On the Semantics of Historical Time. Cambridge (MA). - L: The MIT Press, 1985 [Germ. ed. 1979]. - P. 92 - 104.

7. Hartog F. Regimes d'historicite. Presentisme et experiences du temps. - Paris: Editions du Seuil, 2003 .$288 \mathrm{p}$.

8. Benjamin W. Theses on the Philosophy of History. URL:https://www.sfu.ca/ andrewf/CONCEPT2.html.

9. Chulkov G. I. Collection of works. V. 1: Articles 1905 - 1911 - St. Petersburg: Shipovnik, 1912 -- 249 p.

10. Cattaruzza M. How Much Does Historical Truth Still Matter? // Historein. - 2011 . - No. 11. - P. 49 - 58.

11. Buller A. On the subject and method of the theory of historical knowledge // Logos. - 2001. - No. 5 - 6 (31). - URL: http://www.ruthenia.ru/logos/number/2001_5_6/12.htm.

12. Droysen J. G. Historik, herausgegeben von P. Leyh. - Stuttgart, 1977. - 303 S.

13. Collingwood R. G. Essay on Philosophical Method. - Oxford, 1933. - 240 p.

14. Wrzosek W. Culture and historical truth. - M.: "Krug", 2012. - 336 p.

15. Saltykov-Shchedrin M. Collected Works: in 20 vols. - M.: Hud. lit., 1966. - V. 19. - 552 p.

16. Danilevsky N. Ya. Russia and Europe (1871). - M.: Kniga, 1991.- 577 p.

17. Rückert H. Lehrbuch der Weltgeschichte in organischer Darstellung. - Weigel, 1857. - $600 \mathrm{~S}$.

18. Nadezhdin N. On historical works in Russia // Library for reading. - 1837. - V. 20. - 542 p.

19. Pogodin M. P. Research, remarks and lectures on Russian history: in 7 vols. - M.: University Printing House, 1846 - 1857. - $456 \mathrm{p}$.

20. Strakhov N. Historians without principles (Notes about Renan and Taine) // Rus. - 1886. - No. 8, 9. - 64 p. 
21. Lavrov P. L. Historical letters // Philosophy and Sociology. Selected works in two volumes. V. 2. Academy of Sciences of the USSR. Institute of Philosophy. - M .: Publishing house of socio-economic literature "Mysl", 1965. - 706 p.

22. Gumilev L. N. The end and the beginning again. - M., 2016.- $376 \mathrm{p}$.

23. Mogilnitsky B. G. Historical science and historical consciousness at the turn of the century // Historical science at the turn of the century: All-Russian. scientific conf. materials - Tomsk, 1999. - V. 1. - P. 5 - 17.

24. Gurevich Ya. G. Experience of history methodology // Pedagogical collection. - 1877. - No. 4 - 8. - 579 p.

25. Mitrofanov S. The use of computer technology in the teaching of history at school // History. -2012- No. 18.- P. 9 -11.

26. Huizinga J. Homo Ludens. Articles on the history of culture / Tr. From Dutch by D.V. Silvestrova - M., 1997.- $416 \mathrm{p}$.

27. Ancharov M. L. Collected works. - M.: Lokid, 2001.- 496 p.

28. Yasinsky I. I. Answers to the questionnaire "Revolution and literature" // Freedom and life, 1906. - 52 p.

29. Klyuchevsky V. O. Aphorisms. Historical portraits and essays. - M .: Eksmo, 2007. - 480 p.

30. Prokhanov A., Kugushev S. Technology of the Fifth Empire .- M., 2007. - 330 s.

31. Gdlyan T., Ivanov N. Kremlin case. - M., 1994. - 480 p.

32. Prishvin M. M. Prose of diary. - V. 1. 1918 - 1921. - M., 2007. - $528 \mathrm{~s}$.

33. The historian Sokolov who dismembered his sweet-heart decided to write a book about her murdering. - URL: http://ktv-ray.ru/novost/raschlenivshiy-vozlyublennuyu-istorik-sokolov-reshil-napisatknigu-o-ee-ubiystve/57029/

34. Associate Professor Sokolov intends to share author's emoluments with the juvie. - URL: https://www.gazeta.ru/social/news/2020/01/12/n_13908860.shtml.

35. Bloch M. Apology of history. - M.: Publishing House "Nauka", 1986. - 234 p.

36. Lenin V. I. Materialism and empirio-criticism // Complete works. - M., 1968. - V. 18. - P. 149.

37. Marx K. Theses on Feuerbach // Marx K., Engels F. Works. - M., 1971. - V. 3. - P. 16.

38. Simashenkov P. Aesthetics of History: the example of Russia // Modern European Researches. Salzburg, 2019. - No. 3. - P. 47 - 55.

39. Bergson H. Denken und schöpferisches Werden: Aufsätze und Vorträge. - Frankfurt a. M., 1985. - S. 120.

40. Lavrov P. L. Philosophy and sociology: in 2 vols. - M.: Mysl, 1965. - 403 p.

41. Surkov V. The Long State of Putin // Nezavisimaya Gazeta. - 2019. - Feb 11 - URL: http://www.ng.ru/ideas/2019-02-11/5_7503_surkov.html.

42. Gurevich A. Ya. The double responsibility of the historian // Social sciences and the present. - 2007. - No. 3. - P. $74-84$.

43. Barash J. A. Collective Memory and the Historical Past. - Chicago University Press, 2016. - $280 \mathrm{p}$.

44. Rimondi G. Sobornost as a cultural and philosophical constant of Russian self-consciousness // Cognitive science, mathematics in education. Philosophical problems and practical applications / ed. by V. G. Kuznetsov, V. S. Meskov, N. R. Sabanina. - M.: RUSAINS, 2019 .- p. 257-265.

45. Tendryakov V.F. An attack on mirages. - M.: Soviet writer, 1988. - 400 p. 
Симашенков П.Д. Исследовательский компонент в профессиональной подготовке студентовисториков // Научно-методический электронный журнал «Концепт». - 2020. - № 3 (март). - С.28-39

\author{
Симашенков Павел Дмитриевич, \\ кандидат исторических наук, \\ доцент кафедры государственного и муниципального управления \\ и правового обеспечения государственной службы \\ Самарский университет государственного управления «МИР», \\ г. Самара, Российская Федерация \\ pavel.simashenckov@yandex.ru
}

\title{
ИССЛЕДОВАТЕЛЬСКИЙ КОМПОНЕНТ В ПРОФЕССИОНАЛЬНОЙ ПОДГОТОВКЕ СТУДЕНТОВ-ИСТОРИКОВ
}

Аннотация. Статья посвящена теме "следов прошлого"; актуальность её обусловлена как необходимостью совершенствования подготовки студентов-историков, так и обострением борьбы с фольсификациями истории (в первую очередь - отечественной). Целью исследования является анализ соотношения гуманитарного, социального и технологического компонентов в методике преподавания исторических дисциплин. Ключевым методом избран компаративный; в работе используется метод гипотез, контент-анализ источниковой базы, а также опыт изучения вузовской педагогической практики. Выявляя предпосылки "неверного" изложения былых событий, автор сопоставляет юридический, экспертно-криминалистический, естественнонаучный и философский подходы.

Теоретическая значимость статьи состоит в новизне междисциплинарного, комплексного техно-социо-гуманитарного взгляда на исторические изыскания. По мнению автора, главное - избегать упрощений, геометрической схематизации прошлого, сведения его $\mathrm{k}$ параллелям и нагромождениям дополнительных построений, политизированных спекуляций. Не менее велик соблазн впасть в экзегезу, а из толкователя текстов сделаться собственником стилизации, мета-истории. Задача исследователя состоит в установлении конкретики типичного. Ощущение и осознание принадлежности человечеству обязывает учёного мыслить категориями целостными, комплексными, образными, а вовсе не отвлечёнными. Сама интерсубъективность (даже интра-субъективность) характеризует историю как науку гуманитарную, а не узко-социальную (сродни правоведению или социологии, особенно в их позитивистской трактовке).

Практическое значение исследования заключается в том, что материал статьи может быть использован в педагогическом процессе, а сравнение фундаментальных и прикладных дисциплин поможет студентам-историкам сориентироваться в вопросах профессиональных $и$ мировоззренческих, научит отграничивать непреходящее от суетно-трендового, идеологическое - от тенденциозного. История, полагает автор - о вечно живом, а не про отжившее.

Ключевые слова: история, философия, криминалистика, следоведение, компаративистика. 


\section{Введение}

Не во внутренность её проникнуть настоит нам возможность, но разве уловить малую нить, оставляя существам, человека превышающим, понимать всю связь её деяний.

A. Радищев

Источником вдохновения нам послужили "Три лекции о понятии "след" Андреаса Буллера [1]. Ссылаясь на западные историософские концепции, доктор Буллер обосновывает оригинальное ви́дение проблемы следа в истории, мыслимой отвлеченно и умозрительно. Решимся трактовать вопрос буквально, а потому равно и юридически-конкретно, и ассоциативно, развивая понятийный аппарат упомянутых лекций - намереваясь уяснить, кто (История или Криминалистика) играет на чужом поле. Постараемся пойти дальше сравнения историка с констеблем, сделанного мудрым Робином Коллингвудом [2].

Историческая дистанция не просто неизбежна, она необходима и в чём-то полезна для осознания и оценки прошлого. Наоборот, в детективной практике остывание "горячего следа" осложняет расследование. Продолжая аналогии, нелишне упомянуть о разнице между детективом и полицейским боевиком: в последнем преступник уже известен, и вся прелесть не в умствованиях, а в погоне, в экшене. С историей ещё "проще": там, как правило, не только установлены личности ключевых фигурантов, но известен собственно финал сюжета. Сколь велик соблазн подтасовать следы, погнавшись за сенсацией и подогнав задачку под заранее известный ответ! Уподобление исторических исследований историям детективным, при некотором сходстве в деталях (впрочем, чисто внешнем), в целом выглядит довольно-таки аляповато, а посему предпочтём холмсовой дедукции - индуктивный метод, позволяющий синтезировать, на мой взгляд, более ёмкие обобщения.

Личный двадцатилетний вузовский педагогический стаж даёт моральное право и веские основания утверждать: междисциплинарные связи в освоении гуманитаристики отражены недостаточно полно и внятно (возможно, в силу узости специализации преподавателей). В частности, изучение будущими историками философии, юридических и естественнонаучных предметов мало связано с их профессиональными компетенциями. Полагаю, сравнение фундаментальных и прикладных дисциплин поможет студентам сориентироваться в вопросах исторических и (главное!) мировоззренческих, научит отграничивать непреходящее от суетно-трендового, идеологическое - от тенденциозного. Соответственно, логический строй настоящей статьи обусловлен рассмотрением проблемы "следов в истории" в компаративном, междисциплинарном ключе.

\section{Обзор отечественной и зарубежной литературы}

Образование, подобно очкам, изощряет зрение, но, несоразмерное с глазами, губит их и ослепляет. A. $\Phi$ em

Декларируя за "историко-трасологическим" подходом известную научную новизну, призна́ем однако, что тема следов фрагментарно освещалась - как аспект теории исторического познания. Зарубежных исследователей занимают преимущественно вопросы 
рефлексии. Йорн Рюзен [3] выделял историческую саморефлексию и интеркультурную историографию, Отто Эксле [4] называл историю научно обоснованной памятью современности, Войцех Вжосек [5] говорил, что отношение современной исторической науки к прошлому - особенно отдалённому - является ничем иным, как отношением культуры к другой культуре. Не менее интересен поиск системы координат, очерчивающей режим историзма. Так, Райнхарт Козеллек [6] считает, что исторические интерпретации обусловлены познавательной ситуацией, в которой находится историк; Франсуа Артог [7] развивает тему преобразования памяти в историю; Вальтер Беньямин [8] пишет о зыбком настоящем и постоянстве т.н. Ангела истории. Западные мыслители пытаются упорядочить прошлое схоластически, административно, сверху - будто изобрели и запатентовали абсолютную истину. Результат - мудрёные и опрятные ментальные конструкции, а в сущности - своего рода гольдберг-вариации по мотивам спора тысячелетней давности (между реалистами и номиналистами). Дело в том, что любой парадигмальный орднунг воленс-ноленс фабрикует универсальную “технологию просветления", а неминуемое разочарование в оной породит очередной приступ негативной диалектики. Возможно, по этой причине буржуазная философия пропитана ностальгирующим пессимизмом, эдакой анемией веры: и в познавательные возможности человека, и в высший смысл всего происходящего. Тогда как, по мнению Георгия Чулкова, "история требует от человека мужества, но нельзя быть мужественным, если твоё нравственное сознание непрестанно твердит тебе о греховности всего исторического процесса"[9]. Современные европейские авторы (например, Марина Каттаруза [10]) весьма деликатно и осторожно вписывают мировоззренческий компонент в систему исторического познания. Пожалуй, наиболее "радикальным" в данном плане можно признать красивый афоризм Андреаса Буллера "история - это реализованная во времени мораль" [1 1].

Множество "концептуальных поворотов" (когнитивный, антропологический, психологический, мемориальный и мн. др.) развернуло, в конечном счёте, западный историософский вектор на 360 градусов, мотивируя учёных блуждать в трёх соснах прошлого, будущего и настоящего (пассеизм, футуризм, презентизм). Как следствие - ожидаемые реминисценции: доктор Буллер призывает вооружиться скептицизмом Дройзена и Коллингвуда [12,13], а Вжосек восхищён критическим потенциалом теорий Хладениуса и Вико [14]. Впору вспомнить Салтыкова-Щедрина: “предоставленная исключительно самой себе и обращаясь в среде слишком однородной, мысль может достигнуть результатов болезненных, почти чудовищных"[15].

Отечественная философия органичнее (и отнюдь не в вульгарном, социалэволюционистском изводе дарвинизма) осмысливала идею развития, где явления группируются согласно наблюдениям, установленным закономерностям и выявленным направлениям. Отсюда - естественная упорядоченность, бо́льшая целостность, "художественность" и меньшее количество -измов в попытках объять необъятное (достаточно сопоставить культурно-исторические типы Николая Данилевского [16] и культурные ряды Генриха Рюккерта [17]). Николай Надеждин определял историю как "полное, светлое, живое самосознание каждого народа" [18]. В России историософские моменты интерпретировались преимущественно в ракурсе идеологическом. Михаил Погодин [19] отстаивал теорию официальной народности, Николай Страхов [20] разделял идеи почвенничества; Пётр Лавров [21] связывал историческое развитие с деятельностью критически мыслящих личностей. И позже обозначенное нравственно-эстетическое направление в целом сохранилось. $\mathrm{K}$ 
примеру, Лев Гумилёв [22] разработал учение о пассионариях, а Борис Могильницкий [23] писал о специфичности исторических законов и альтернативности познания.

Этический лейтмотив прослеживается и в отечественной педагогической литературе. Уже в первом российском учебнике по методике преподавания истории (1877 г.) автор его, Яков Гуревич, убеждал "посредством сообщения материала и способа передачи его влиять на нравственное и умственное развитие учащихся... Для этого нет надобности скрывать $и$ мрачные явления в истории народа и выдвигать одни лишь светлые явления в жизни его. Для этого незачем идеализировать прошлое своего народа и унижать значение других народов: такой слепой патриотизм совершенно противен чувству правды и гуманности, развитие которых школа должна иметь в виду" [24]. Современный взгляд на проблему "цифровизации преподавания истории" - в русле все той же гражданственно-патриотической доминанты [25].

Таким образом, отечественная и зарубежная историософские школы, выражаясь юридически, являют собой образцы прецедентного и нормативистского подходов к оценке доказательств. Первый идёт от традиций и аналогий, второй - от формально установленных предписаний; один ориентирован на систему и принципы, другой - на структуру и догмы. Словом, западная философия сильна правилами, а русская жива исключениями.

\section{Методологическая база исследования}

Наше лучшее существует безуступно и будет существовать и утвердится, перелетев через головы современной диктатуры мелкоты. М. Пришвин

Изысканная по фразеологии, зарубежная "историка" (как там принято именовать философию дисциплины) придавлена “культурным слоем” терминов (учредительный миф, культурный код, аксиологическая нейтральность, социокультурный фактор и т.п.), коих объяснение достойно выделения в самостийную квазинаучную дисциплину. Посему не удивляет ни обилие словопрений и зачастую надуманных поводов для дискуссий, ни появление "полицейских" формулировок, как то: исторические приписки, фальсификации, инсценировки, ложные заключения, квалификация смысла явлений, - отчего историография мало-помалу мутирует в графологию (признанную, кстати, лженаукой). Создается впечатление, будто все усилия предков направлялись единственно на сокрытие следов и уход от ответственности. Но что есть историческая ответственность и (главное) - когда и перед кем отвечать? Нам данная постановка вопроса представляется принципиальной, поскольку позволит отличить провиденциалистов от детерминистов, а искусство - от искусственности и ремеслухи. На наш взгляд, западный курс на “легитимацию" историкопостижения во многом ошибочен. Казуистика дистиллирует историю, а абсолютизация "объективности" - не более чем проявление гордыни (вознамерившейся приватизировать истину), т.е. самого махрового субъективизма.

В юридических координатах "объективного-субъективного" легко выявляются "родовые проклятия" историков: формализм и тенденциозность (соотносимые, скорее всего, как причина и следствие). Применительно к теме следов и расследования, формализм - вообще критерий структурообразующий. Неужто миссия историка ограничится одними лишь полномочиями эксперта, собирающего и анализирующего улики? При таком раскладе функция эксперта - дать однозначный (не вероятностный) ответ на вопросы, поставленные 
исходя из сформированной следственной версии. А версия есть не что иное, как поляризованная (вариант: тенденциозная) картина событий, коль скоро процесс разделен на стороны обвинения и защиты. Значит, центральной становится проблема точности, конкретики выводов. Именно безоговорочность экспертной оценки ценится здесь особенно высоко, ибо право по определению есть тёмный лес оговорок, где каждый юрист - Сусанин, $и$ нет ни одного Данко.

Знаменательно: юридическая риторика уже более полувека присутствует в “протокольных" оборотах научных цитат (“по заявлению Леонтьева, Бердяев сознавал, Белинский позже раскаивался, по признанию Карамзина, Нестор прямо указывает, Герцен свидетельствует" и проч.) Исторические персонажи беззащитны перед (ис)следователями, практикующими допросы с пристрастием, манипулируя сведениями, которые не всегда аргументы и факты. В отличие от показаний, даже мемуарные источники не интерактивны; они - своеобразные ответы без вопросов, подписанный чистый лист протокола, который может быть собственноручно дописан нечистоплотным детективом. Получается, при неявке (ввиду смерти) самого фигуранта его собственное, запечатлённое в следах, признание формально и есть Regina probationum. Благодаря такому “объективному вменению" и появляются незатейливые гипотезы - вроде той, будто Афанасий Никитин принял ислам (о чем якобы свидетельствует "мусульманские" пассажи в его "Хожении за три моря"), или что упомянутая нами "царица доказательств" есть афоризм прокурора Вышинского.

Итак, корень формализма - в не-избирательности метода, т.к. методика исследования должна быть утверждена компетентной инстанцией. В противном случае результаты экспертизы нельзя признать доказательством. Более того, судебный эксперт несёт ответственность за заведомо ложное заключение, но ответственен ли учёный, и вновь - "а судьи кто?" Безусловно, от века чаемый суд истории заслушает и историка: как эксперта либо свидетеля. Последнее хуже, ибо презюмирует недоверие: на каком основании тот вознамерился оценивать события? Истину не устанавливают и не восстанавливают (кто ее ронял?), её обретают. Здесь откровение выше формальной логики, диагностика вернее идентификации, а учение ценнее методички. Наверно, поэтому фраза "история нас рассудит" будет актуальной до самого Страшного Суда; на него-то и уповают ушедшие - как на ордалии, отличавшиеся от пыток тем, что назначались и по просьбе ответчиков. В этом, думаю, проявляется надежда людей на высшую юстицию, безотносительную к буквоедству и крючкотворству.

Усугубим наши рассуждения о правовой архаике ещё одним тезисом: правда всегда "варварская", она не бесстрастно-благородная "истина". Историк не только следователь, но также потерпевший (как все смертные): и от истории, бывает - и за историю. Значит, потребность самому разыскать, изобличить и взыскать с виновного на глазах у общества очень в духе приснопамятных leges barbarorum. Допустимо ли всерьёз говорить о полной незаинтересованности историков в результатах их же изысканий? Особенно в эпоху политизации всего и вся, когда в цене разжигание нездорового интереса любыми средствами, не гнушаясь нуар-пиаром и иными непотребными связями с общественностью. По мнению Йохана Хёйзинги [26], "историческое знание представляет собой одну из форм, в которых общество даёт себе самоотчёт”. Хочется верить, что и отчитывает не сам историк, да и подотчётные - не homo ludens или homo politicus, а люди серьёзные. На наш взгляд, значима моральная готовность человека стать орудием правосудия, но многие ли обладают подобной самоотверженностью? В обычном праве (lex communis) мерилом содеянного почитались 
нравственные ценности, априори превосходящие формализм. В конце концов, для чего суд: ради наказания или ad maiorem Dei gloriam inque hominum salutem? И сподобится истины лишь тот, кто и в "варварской правде" проникся сопричастностью общему делу, готовый постоять за справедливость и жить "за того парня". Это подразумевает более высокую инстанцию - соборную Личность. Словами Михаила Анчарова, “чтобы понять себя, человек должен стать сложнее се6я. А что может быть выше человека? - Человечество!" [27]

Следование в большей мере исповедание, чем следствие и расследование. Существует, однако, и упрощённо-утилитарный вариант "от лукавого" - преследование (скажем, ревизионизм - как средство посчитаться с умершими и тем снискать дешёвый авторитет). События и следы, всегда рельефнее в косопадающем свете: в историческом контексте нехитрый оптический приём выглядит практически апологией тенденциозности. Примечательно: до эпохи Просвещения хронисты и летописцы едва ли опасались сего греха. Вероятно, оттого, что подо6но Иерониму Ясинскому, считали тенденциозность "неискренностью и родной сестрой бездарности" [28], ведь они создавали свои опусы, стараясь не оскорбить Вечность пошлостью. Криминалистическая редукция истории ведёт к стандартизации методик исследования, низводя их до алгоритмов. Так сподручней измышлять сенсационные разоблачения, спекулируя архивным компроматом. "Элементарно, Ватсон!" - вот откуда нынешний спрос на конспирологию и "исторические" детективы а-ля Дэн Браун.

Тенденциозная подтасовка - разновидность фальсификации, повод и средство мастерить мифы и лепить исторические стереотипы. В законотворчестве отражается девальвация ценностей - стало быть, закономерно спрогнозировать скелетирование исторической науки до тенденций, всегда схематичных, а потому карикатурных. И если оценивать ход времени в духе правового принципа неотвратимости, то историзм есть термин негативный, почти суде6но-медицинский. Действительно, проще засвидетельствовать крах и распад как отсутствие признаков жизни, а присутствие её - вопрос куда более тонкий и менее объективный (тут эксперт в лучшем случае пытается квалифицировать тяжесть повреждений, опять - как отсутствие здоровья, т.е. целостности организма). Воистину, "весь успех естествознания в том, что центр внимания перенесён с причин на следствия" [29].

Подчеркнём: мы не отрицаем значимости техно-криминалистического компонента исследований в частных отраслях - археологии (где родство, пожалуй, наибольшее), палеографии, ономастике. Куда осторожнее следует “детективизировать" сферы более общие. Каждый учёный где-то самоуправствует и творит самосуд, однако сомнительно, что неминуемый "суд истории" станет проводиться заочно и лишь по материалам историографии. Ощущение принадлежности человечеству обязывает историка мыслить категориями целостными, комплексными, образными, а вовсе не отвлечёнными. Сама интерсубъективность (даже интра-субъективность) характеризует историю как науку гуманитарную, а не узко-социальную (сродни правоведению или социологии, особливо в позитивистской трактовке). Не пристало истории заигрывать и с технологичностью, немыслимой без проектного подхода и присущей ему ограниченности вследствие "слабоумного изумления перед своим веком" (пушкинская фраза). Тенденциозность есть категория не мировоззренческая; наоборот, она обусловлена растяжимостью жизненных ориентиров (не принципов) и произрастает из пошлого стремления к самореализации. Лучшее средство от тенденциозности - принципиальность (вне идеологии способная, однако, выродиться в ригоризм). Личность должна вызывать и оправдывать доверие - в этом 
родственны требования и к судебному эксперту, и к учёному. Но что доверить и как доверять нравственно-аморфному субъекту? И "кто более матери-истории ценен": самоутверждающийся политикан-критикан - или многозначительно молчаливый "след"?

Контекст исторического дискурса обыкновенно задаётся действительностью, когда нужно оценить прошлое, дабы осознать своё место в настоящем. Предков неприятно удивил бы интерес учёных к их окаменевшим фекалиям, ведь грядущим поколениям храмы оставляли! Раньше хроники описывали деяния королей, героев и святых, ныне же каждая социальная инфузория мнит себя туфелькой от Лабутена и сама себе блогер. Вместо истории - инстасториз, негодные покушения на захламление вечности типовым контентом. Благодаря СМИ жизнь превращена в сплошной мутный поток неосознанного бытия. Иными словами, следов и охотников наследить - масса, но все сходны до степени смешения, практически неразличимы ибо обезличены.

В такой "обстановке неочевидности" историку потребны не столько приёмы идентификации, сколько таланты диагностики и атрибуции (которая есть поиск типичного в рыхлой совокупности типового). Это предполагает присутствие внутреннего убеждения, своеобразного "инстинкта истины" при оценке доказательств. Выходит, уже на стадии фиксации следов криминалистический детерминизм должен почтительно уступить место методам менее точным и материям более тонким. Подобно тому, как глазу художника не дано запечатлеть движущихся предметов, эстетика истории - в её статике, вечных ценностях, а всё преходящее - тенденциозный декор. Издавна считалось выгодным шарлатанствовать: угождая вре́менной конъюнктуре, эффектно приносить в жертву временны́е закономерности, отождествляя их с совпадениями, выдавая симптомы за синдромы. Взять хотя бы нынешний ассортимент наукообразного кича: поп-хистори, фолк-хистори, альтернатив-хистори еєс. И всё же в исторической перспективе заказные покрово-облачения [30] и покрово-срывания [31] равно обречены на забвение. Или на проклятие, как случилась с кликушами перестроечной эпохи. А нравственная чистота будет вдохновлять и далёких потомков.

\section{Результаты исследования}

Не вместить эту череду, вереницу смертей в одно своё, и тоже бренное, бытие.

Нет, не помнить - но чуять сердцем, душою! Д. Балашов

Достоинство исследователя не столько в отстранённой объективности, сколько в добродетелях совестливости и смирения: поменьше "любить себя в искусстве". Совесть выше рефлексии, это светловское “как я встану перед миром, как он взглянет на меня?" В данном плане яркий пример - летописцы. Осмелимся предположить, что история Руси написана внутренними эмигрантами - иноками, чуждыми политике, успеху и самореализации. Конечно, события в их изложении смешивались с легендами, знамениям и слухами. Тем не менее, слухи эти были (в известном смысле) срезом общественного мнения. Словом, летописная традиция скорее верна, нежели точна: дух времени в ней не засорялся бухгалтерией фактов.

Задача историка состоит в установлении конкретики типичного. Чрезвычайно сложно нащупать "срединный нерв" эпохи, но, полагаем, только так уясняют "субъективную сторону" деяния в историософском ключе. Михаил Пришвин определял тип как "общественную кристаллизацию бывшей некогда индивидуальности" [32]. К примеру, трагедия Раскольникова 
экстраординарная и контрастирует с типовым антуражем “достоевского Петербурга". А вот история "Распильщикова", питерского доцента-потрошителя [33], напротив, пугающе типична для эры вялотекущего прорыва. Она однозначна и одномерна, это дикость в высшей степени концентрации, вобравшая в себя и постановочный патриотизм, и ряженую науку, и ролевые игры, и пятьдесят оттенков адюльтер-волонтёрства. Иллюзорная жизнь, шоу-смерть, менеджмент преступления и маркетинг наказания [34]. Любопытно, насколько виновен Наполеон Бонапарт в обоих убийствах, что на это скажут историки, реконструкторы и криминалисты?

Каждый хочет оставить после себя житие или хотя бы некролог, но никак не анкету. Дух эпохи невозможно почувствовать, не зная отношения живших тогда людей к небытию. "Memento mori" настраивает вектор "незряшности" жизни, ибо от жизни - следы, а у смерти признаки (припомним расхожую фразу “в моей смерти прошу винить мою жизнь"). Как говорил Василий Ключевский, природа рождает людей, жизнь их хоронит, а история воскрешает, блуждая по их могилам. Следы запечатлены и в приметах умирания, кризиса, инволюции как процессов (а смерть - фатальный результат). Необходимо различать ориентирующие и достоверные признаки смерти, то же - в анализе упадка империй и цивилизаций (первые не выдерживают испытания величием, вторые - сытостью). Симптоматика деградации безотносительна к месту и времени. Как, впрочем, и характер "суправитальных реакций" почившей империи: когда её тщатся восстановить в отдельных проявлениях, реконструировать техно-уродливо, продукт непременно напоминает Голема или монстра Франкенштейна. Итак, мёртвое есть следовоспринимающий объект, тогда как живое следообразующий. Получается, история нерукотворно писана на саване биологической антропологии, подобно чуду Туринской плащаницы!

Наконец, определимся, чем считать след: или он - доказательство per se, или только источник доказательств. Либо он просто продукт исторического метаболизма, либо атрибут вечности (и тогда сам исследователь - персона куда более эфемерная и фигуральная). Формула Марка Блока определяет след как "доступный нашим чувствам знак, оставленный феноменом, который сам по себе для нас недоступен" [35]. Заметим: недоступность в плане истории, как и в криминалистике, не столько физическая, сколько процессуальная, т.е., в конечно счете, обрядовая, идеологическая. К тому же, упомянутый феномен ("реальность, данная нам В ощущениях"[36]) может иметь разную природу; тут опасно делать непосредственные заключения, отождествляя феномен с фактом, а след - с источником. Нам представляется, след в истории есть отображение, причём всегда идеальное (пусть даже на материальном носителе), запечатлённое в сознании и культурной памяти. В исторических исследованиях особенно трудно разграничить след и субстрат, на котором тот выделяется. Стало быть, считать его знаком или нет, во многом зависит от восприятия.

Что на ком оставляет след - вот вопрос. По Марксу, "до тех пор, пока существуют люди, история природы и история людей взаимно обусловливают друг друга" [37]. Оценка прошлого близка к правде, если неопровержима ни новыми источниками, вводимыми в научный оборот, ни свежими археологическими открытиями. В переводе на юридический язык, квалификация содеянного верна, когда вновь открывшиеся обстоятельства не способны кардинально её изменить. Таким образом, изучая оставленный знак, мы должны "возвысить" его от контента и контекста до общего понимания ситуации, ведь и время исцеляет именно в смысле восстановления целостного представления о былом. Как всегда, обретение подобного восприятия запросто вульгаризовать до приведения к одному знаменателю (а то и знамению). 
Унифицировать взгляд на человечество и его историю можно лишь с точки зрения глупости, что блестяще доказано Эразмом Роттердамским. Но сие не повод ставить глупость и смерть в ряд общечеловеческих ценностей.

Ёмкий афоризм Тимофея Грановского "в разложении масс мыслию заключается процесс истории" можно интерпретировать и в прогрессивном и в регрессивном плане. На наш взгляд, способность уловить, опознать дух времени в конкретных приметах требует не только информированности о фактах. В опознании больше искусства, чем в следственноэкспериментальных реконструкциях. Здесь огромную роль играют особые приметы, консонансы и диссонансы, "сильные и слабые доли", т.е. события потрясшие и те, что уже перестают удивлять современников - образно говоря, по ним выверяют "пульсовое давление" истории. Безусловно, указанная точка зрения пригоднее для изучения естественных социальных тенденций, коими являются только измельчание и вырождение [38]. Пресловутый "ход вещей" - роковое клеймо, статический след, штемпель базиса политэкономической действительности. Историю масс пишут по этой канве (влияние событий на людей), персоналии же характеризуют, обозначая отношение личности к судьбоносным событиям и участие в них. Если история не зациклена и развивается - значит, в массе обозначилась мыслящая личность; кто-то нарушил, превзошёл законы причинности, сотворив собственный контекст. Выдающиеся, творческие личности оставляют в душе народа след динамический (влияние), и чем глубже, тем более хара́ктерна история. Это “идентификаторы" истории, индивидуализирующие культуру. Подобные моменты тонко чувствовал Алексей Хомяков, оттого его историософия выше формальной системности, логичности и линейности (с другой стороны, её нельзя назвать бессистемной, алогичной и нелинейной: Хомяков не мыслил альтернативами, как до сих пор принято на Западе). По большому счёту, суть истории неизменна. Со времен древнегреческих трагедий, она в отношениях героя, хора и богов: личности, личин и -измов, стремящихся её оприходовать.

\section{Заключение}

...древнею добротою возобразитися...

(Тропари по непорочных, глас 5-й)

Наследуя предкам, мы следуем за ними, и парадоксально - в будущее, навстречу человечеству. Но какой наследник из ведущего следствие по делу наследодателя? Кто всётаки историк: эксперт, присяжный, судья, медиатор или медиум? Не делает ли историю посредственной (mediocre) опосредованность обилием несознаваемой информации?

Актуальное отделяет и отдаляет нас от вечности. По Анри Бергсону, "как только действительность сотворит из себя нечто непредсказуемое или новое, она бросает своё изображение позади себя в своё неопределённое прошлое"[39]. Возразим: действительность имеет тварную природу, сама же не творит. Действительность есть опошленная обыденностью реальность, дагерротип реального, оборачивающийся то позитивом, то негативом - сообразно углу зрения. Признавая провиденциальный характер истории, мы скорее будем ориентироваться на непреходящее - следовательно, превосходить законы, коль скоро те регулируют лишь механизмы инволюции и траекторию падения. Мода на пророчества - от утраты чувства реальности. В действительности пророчества на слуху там, где её считают хаотичной. Профетизм редко оптимистичен, ведь прогресс это мечта, а не пророчество. Да и прорицание - не откровение, пророчества всегда сбываются задним 
числом (в таком виде и сбываются массам). Важно не ожесточиться злобой дня, дабы за частным не проглядеть общее.

На пути исследования главное - избегать упрощений, геометрической схематизации истории, сведения её к параллелям и нагромождениям дополнительных построений, политизированных спекуляций и универсальных техно-философских "мультиварок смыслов". Негоже превращать знаменитый хайдеггеровский "дазайн" в броский словесный дизайн, как ранее психоанализ опошлили до голливудской фрейдятины, объясняющей "типа всё". Мыслительные контрафакты (несуразные обобщения и фальшивые актуализации) искушают доступностью, тем опаснее путать исторические труды с обвинительными заключениями. Не менее велик соблазн впасть в экзегезу, а из толкователя текстов сделаться собственником стилизации, мета-истории, авторских "эксклюзивных" миров (неспроста столь популярны “лживые саги" а-ля Поттериана или Средиземье). В годину тотальной цифровизации, когда бытие опережает сознание и мир скатывается к виртуальной фикции (ложь и лицемерие уже именуют цифровым интеллектом), чувство реальности поддерживается исключительно памятью. Инстинкт культурного самосохранения проявляется в тяге к подлинному, а оно, настоящее, всегда в прошлом - сие неоспоримо, как преюдициальный факт.

История тем именно отличается от процессов природы, что “в ней явления не повторяются, и происходящее остается для неё лишь воспоминанием"[40]. Культурной памятью усложняется архаика и реставрируется (не реконструируется!) облагороженный образ. Прошлое - не всегда прошедшее, оно живёт в нас. Как у Тютчева: "я встретил вас, и всё былое в отжившем сердце ожило... и вот слышнее стали звуки, не умолкавшие во мне". Былое это прошлое, которое не прошло. А утраченные моменты суть пробелы, требующие восполнения без разрушения гармонии (поэтому некоторые из них тактично заполняются молчанием). "Новое есть хорошо забытое старое” - отнюдь не банальность; правда, в новизне сложно порой отличить "дух истории" от душного ретро-амбре. Так, искусственные потуги казённого мифотворчества, тэгирования и брендирования истории "глубинным народом" [41] и "\#можемповторить" делают нынешние скрепно-державные панегирики антиисторичными и антинародными. Разумеется, мы далеки от декларации "партийности" криминалистики (тем паче - истории), однако и старый принцип "cujus regio, ejus religio" нельзя сбрасывать со счетов, постигая нечто слишком человеческое. Арон Гуревич признавал презумпцию "инаковости" постулатом исторического познания [42]. По нашему убеждению, проблема не в "инаковости", но в осознании родства искомой культуре. А историк всегда исследует культуру, занимаясь ли персоналиями, артефактами или событиями. Не ощущая этой духовной, почти мистической со-временности (как в романе Тима Пауэрса "Врата Анубиса") грех покушаться на расшифровку символики “следов". Родная быль всегда ближе, открывать её - более ответственно и перед собой, и перед предками.

Критическое направление в историографии будет первенствовать, покуда не изживёт се6я подражательность (nigredo). Следовательно, народность истории - необходимая стадия (albedo) синтеза коллективной памяти и национальной культуры в память co6орную (rubedo). Отметим: наиболее проницательные из зарубежных учёных [43,44] на пути к осознанию важности культурной памяти (как камертона историзма) и роли соборной Личности в её формировании. История есть достояние человечества, единство с которым нам всем однажды предстоит осознать.

Вопросы соразмерности памяти и истории напоминают споры о6 отличии пресуществления от претворения. Снова дефиниции: если рассматривать память как 
физиологическую функцию мозга, история неизмеримо выше любой памяти. Наоборот, признавая последнюю вселенским хранилищем знания и опыта, историю следует считать одной из кладовых, откуда можно извлекать информацию под стать средствам обнаружения и фиксации. Как видим, второй подход рискует стать откровенно технологичным и самонадеянно-самодостаточным, как всё технологичное. Камень преткновения - в селективности памяти (особенно исторической); секрет её до сих пор не раскрыт, эта селективность и позволяет уповать на "суд истории". Вероятно, истина откроется даже судом не истории, а над ней, что и произойдёт в Судный День.

Согласно парадоксу Владимира Тендрякова, "история - наиболее динамический процесс в природе. Историческая же наука, увы, едва ли не самая статичная из всех наук"[45]. Наше истолкование: статичная - ибо так или иначе ориентирована на деяния надисторических личностей. Словами Петра Лаврова, это "мученики, легенда которых переросла бы далеко их истинное достоинство. В их уста вложат лучшую мысль, до которой доработались их последователи. Они станут недосягаемым идеалом пред толпою". В массах человечность присутствует в следовых количествах, а т.н. общество - не более чем след соборного человечества на Земле. Поэты, мудрецы, святые, революционеры всех времён и народов духовно родственны и преемственны, они вселяют надежду на существование человечества, которое и есть олицетворённый прогресс. Иными словами, образуют постоянную составляющую исторического тока, в то время как прогресс безличный, но видимый (научно-технический) формирует его переменную величину и обнаруживается в толще масс. Получается, последние одновременно являются и следообразующим и следовоспринимающим объектом, а сугубо следоведческое их изучение ограничивает историю социальным (объективным) компонентом, в ущерб гуманитарному.

Мы уверены: общий исход (не цель) - в историософском претворении всех исторических дисциплин, подобно тому как юридические отрасли дорастут когда-нибудь до первоисточника (теории государства и права). В культурной памяти живёт эон, история же, увы, всё чаще довольствуется хроносом. Не стоит смешивать детализацию с мелочностью и низводить поэзию антропологии до прозы и фразы. История, по нашему мнению - о вечно живом, а не про отжившее.

\section{Ссылки на источники}

1. Буллер А. Три лекции о понятии "след". - М.: Алетейя, 2016. - 128c.

2. Collingwood R. G. The Idea of History. - Oxford University Press, 1994. - 576p

3. Rüsen J. Some Theoretical Approaches to Intercultural Comparative Historiography // History and Theory. 1996. Vol. 35. Theme Issue: Chinese Historiography in Comparative Perspective / Ed. by Axel Schneider and Susanne Weigelin-Schwiedrzik. - P. 5-22

4. Эксле О.Г. Культура, наука о культуре, историческая наука о культуре: размышления о повороте в сторону наук о культуре // Одиссей. Человек в истории. М.: Наука, 2003. - С. 393-416

5. Wrzosek, W. In Search of Historical Time. An Essay on Time, Culture and History. In Topolski, J. (ed.), Narration and Explanation. Contributions to the Methodology of the Historical Research (seria Poznań Studies in the Philosophy of Sciences and Humanities 41).- Atlanta-Amsterdam, 1990. - P.1 19-131

6. Koselleck R. Futures Past. On the Semantics of Historical Time. Cambridge (MA); - L: The MIT Press, 1985 [Germ. ed. 1979]. - P. 92-104

7. Hartog F. Regimes d'historicite. Presentisme et experiences du temps. - Paris: Editions du Seuil, 2003. 288p.

8. Benjamin W. Theses on the Philosophy of History - URL: https://www.sfu.ca/ andrewf/CONCEPT2.html 
9. Чулков Г.И. Сочинения : Т. 1:Статьи 1905-1911 гг. - СПб. : Шиповник, 1912. - 249 с

10. Cattaruzza M. How Much Does Historical Truth Still Matter? // Historein, 2011 . - № 11 - P.49-58

11. А. Буллер. О предмете и методе теории исторического познания // Логос, 2001. №5-6 (31) - URL: http://www.ruthenia.ru/logos/number/2001_5_6/12.htm

12. Droysen J. G., Historik, herausgegeben von P. Leyh, - Stuttgart, 1977. - $303 \mathrm{~s}$.

13. Collingwood R. G. Essay on Philosophical Method. - Oxford, 1933. - 240p.

14. Вжосек, В. Культура и историческая истина. - М.: «Кругъ», 2012. - 336с.

15. Салтыков-Щедрин М. Собрание сочинений в 20 т. / Салтыков- ЩедринМ. - М.: Художественная литература, 1966. - Т. 19. - 552 с.

16. Данилевский Н.Я. Россия и Европа (1871). - М.: Книга, 1991. - 577с.

17. Rückert H. Lehrbuch der Weltgeschichte in organischer Darstellung. Weigel, 1857. - 600s.

18. Надеждинъ Н. Объ историческихъ трудахъ въ Россіи // Библіотека для чтенія", - т.20, 1837, - 542с.

19. Погодин М. П. Исследования, замечания и лекции о русской истории: В 7 т. - М.: Университетская типография, 1846-1857. - 456с.

20. Страховъ Н. Историки безъ принциповъ (Заметки объ Ренане и Тэне) // Русь. 1886, - №8,9. - 64с.

21. Лавров П.Л. Исторические письма. В кн.: Философия и социология. Избранные произведения в двух томах. Т. 2. Академия наук СССР. Институт философии. - М., Издательство социальноэкономической литературы "Мысль", 1965. - 706с.

22. Гумилев Л.Н. Конец и вновь начало. - М., 2016. - 376с.

23. Могильницкий Б.Г. Историческая наука и историческое сознание на рубеже веков // Историческая наука на рубеже веков. Материалы Всероссийской научной конференции. - Томск, 1999. - T. 1. - С. 5-17

24. Гуревич Я.Г. Опыт методики истории // Педагогический сборник, 1877 (№4-8). - 579 с.

25. Митрофанов С. Использование компьютерных технологий в преподавании истории в школе // История.- 8-15 мая 2012.- №18.- С.9-11.

26. Хёйзинга Й. Homo Ludens; Статьи по истории культуры. / Пер. с гол. Д. В. Сильвестрова - М. 1997, $416 \mathrm{c}$.

27. Анчаров М.Л. Сочинения. - М.: Локид, 2001, -496с.

28. Ясинский И.И. Ответы на анкету «Революция и литература» // Свобода и жизнь, 1906. 52с.

29. Ключевский В.О. Афоризмы. Исторические портреты и очерки. - М.:Эксмо, 2007, - 480с.

30. Проханов А., Кугушев С. Технологии пятой империи. - М. 2007. - 330с.

31. Гдлян Т., Иванов Н. Кремлёвское дело. - М., 1994, - 480с.

32. Пришвин М.М. Дневниковая проза. - Т.1. 1918-1921. - М.2007, - 528с.

33. Расчленивший возлюбленную историк Соколов решил написать книгу о ее убийстве. - URL: http://ktv-ray.ru/novost/raschlenivshiy-vozlyublennuyu-istorik-sokolov-reshil-napisat-knigu-o-eeubiystve/57029/

34. Доцент Соколов намерен поделиться с колонией гонораром за роман. - URL: https://www.gazeta.ru/social/news/2020/01/12/n_13908860.shtml

35. Блок М. Апология истории. - М.: Изд-во «Наука», 1986. - 234с.

36. Ленин В.И. Материализм и эмпириокритицизм. - ПСС. - М., 1968, - Т.18. - С.149

37. Маркс М. Тезисы о Фейербахе. В кн.: К.Маркс, Ф. Энгельс. Сочинения. - М., 1971. - Т.3. - С.16

38. Simashenkov P. Aesthetics of History: the example of Russia // Modern European Researches. Salzburg, 2019. - №3. - P. 47-55

39. Bergson, H. Denken und schöpferisches Werden: Aufsätze und Vorträge. - Frankfurt. a. M. 1985, S. 120

40. Лавров П. Л. Философия и социология: В 2 т. - М.: Мысль, 1965-- 403С.

41. Сурков В. Долгое государство Путина // Независимая газета. 11.02.2019. - URL: http://www.ng.ru/ideas/2019-02-11/5_7503_surkov.html

42. Гуревич А.Я. Двоякая ответственность историка // Общественные науки и современность. 2007. №3. - C.74-84

43. Barash J.A. Collective Memory and the Historical Past. -Chicago University Press, 2016. - 280p. 
44. Римонди Дж.Соборность как культурно-философская константа русского самосознания. В кн.: Когнитивистика, матетика в образовании. Философские проблемы и практические приложения / под ред. В.Г. Кузнецова, В.С. Меськова, Н.Р. Сабаниной. - Москва : РУСАЙНС, 2019. - С.257-265

45. Тендряков В.Ф. Покушение на миражи. - М.: Советский писатель, 1988. - 400с. 